Title: Judicial Control of the Guardian - Explaining Patterns of Governmental Annulment Litigation against the European Commission

Author(s): Adam, C.; Bauer, M. W.; Hartlapp, M.

Document type: Postprint

Terms of Use: $\quad$ Copyright applies. A non-exclusive, non-transferable and limited right to use is granted. This document is intended solely for personal, non-commercial use.

Citation:

Adam, C., Bauer, M. W., \& Hartlapp, M. (2018). Judicial Control of the Guardian - Explaining Patterns of Governmental Annulment Litigation against the European Commission. In J. Ege, M. W. Bauer, \& S. Becker (Eds.), The European Commission in Turbulent Times: Assessing Organizational Change and Policy Impact (pp. 85-112). https://doi.org/10.5771/9783845287560-85 


\section{Chapter 4: Judicial Control of the Guardian - Explaining Patterns of Governmental Annulment Litigation against the European Commission}

\section{Christian Adam, Michael W. Bauer, Miriam Hartlapp}

\section{Judicial Control of the Guardian}

Dr. Christian Adam, LMU München, Prof. Dr. Michael W. Bauer, Prof. Dr. Miriam Hartlapp

Abstract: This chapter investigates actions for annulment. Annulment actions constitute a central yet by-and-large neglected device of judicial review in the European Union. We focus on cases in which member states take the European Commission to the Court of Justice of the European Union in order to fend off interferences with domestic policy application. Specifically, we ask when and why member states initiate such actions for annulment. To assess the validity of different answers to this question, we use data on the frequency of annulment litigation and evaluate the impact of four potential explanatory factors: the creative agency of the supervising Commission, the inept application of EU law by a shirking agent government, the heterogeneity of preferences held by the collective principal (i.e., the Council), and the interruption of the relationship between the commission and member state governments.

Zusammenfassung: Gegenstand der Analyse in diesem Kapitel sind Nichtigkeitsklagen vor dem Europäischen Gerichtshof. Nichtigkeitsklagen sind eine zentrale, aber bisher weitgehend unerforschte Kategorie der Normenkontrolle im EU System. Wir untersuchen solche Klagefälle, in denen Mitgliedstaaten, um Eingriffe in nationale Politikgestaltung abzuwehren, die Europäische Kommission vor dem Europäischen Gerichtshof verklagen. Wann und warum entscheiden sich nationale Regierungen für eine solche Nichtigkeitsklage? Um diese Frage zu beantworten werden vier potentielle Erklärungsfaktoren mit Hilfe von quantitativen Daten zur Häufigkeit der Klageerhebung in der EU-15 getestet: kreatives Handeln der Kommission als Agentin, unangemessene Anwendung durch eine pflichtverletzende nationale Regierung, heterogene Präferenzen im Rat als kollektivem Prinzipal und die Unterbrechung der Beziehung zwischen 
Kommission und mitgliedstaatlicher Regierung, z.B. durch Wahlen oder die Benennung eines neuen Kommissars. noindent

\section{Introduction}

When the Court of Justice was founded as part of the European Coal and Steel Community, one key rationale behind its creation was the establishment of a mechanism through which the High Authority-as precursor to the European Commission (hereinafter referred to as "the Commission")—could be kept in check (Alter 1998, 124). To do so, member states were granted the right to initiate actions for annulment and have the Court review the legality of actions of the High Authority. In fact, action for annulment (today defined through Article 263 TFEU ${ }^{1}$ ) is still the central instrument for subjecting supranational legal acts to judicial review. Member states can ask the Court of Justice of the European Union (CJEU $)^{2}$ to review the legality of legal acts adopted by the Commission. Actions for annulment are thus a key instrument with which member states of the European Union control the actions of the Commission in its double function as their agent and as the guardian of the treaties. Yet in stark contrast to other legal instruments, such as preliminary reference and infringement proceedings, actions for annulment have remainedwith only few notable exceptions ${ }^{3}$ - largely neglected by political science scholarship. ${ }^{4}$

1 TFEU stands for the Treaty on the Functioning of the European Union.

2 The Court of Justice of the European Union consists of two major courts: the General Court and the Court of Justice, also known informally as the European Court of Justice. It is the latter to which we refer as CJEU and as "the Court" in this paper.

3 See Adam, Bauer and Hartlapp 2015, Adam 2016; Bauer and Hartlapp 2010; Hartlapp and Bauer 2011; Jupille 2004; or McCown 2003.

4 The three main channels through which the CJEU may deliver a judgment in legal disputes within the EU are infringement proceedings, preliminary rulings, and annulment proceedings. The infringement procedure, set out in Article 258 of the Treaty on the Functioning of the European Union (TFEU), allows the Commission and the CJEU to deal with member states' infringements of EU law. Most of the time it is used when a member state has not transposed an EU directive correctly or on time, or is applying single-market rules incorrectly. The key function of preliminary rulings is to ensure a harmonized application of EU law by national courts. Article 267 of the TFEU enables 
This chapter addresses this research gap and analyzes when and why national governments make use of this "defense" instrument and initiate actions for annulment against the European Commission. To do so, data on the frequency of annulment litigation are analyzed.

The chapter contributes to three strands of literature. First, it contributes to research on compliance in the EU, which generally distinguishes between correct policy transposition and correct policy application. The empirical perspective of this line of research is heavily biased toward the analysis of conflict over transposition delay (Steunenberg and Toshkov 2009; Toshkov 2008; Thomson 2010; König and Luetgert 2008). ${ }^{5}$ By capturing instances of judicialized conflict over policy application between the Commission and the member states, a focus on actions for annulment promises to complement this biased perspective.

Second, our focus contributes to the vast literature on the relationship between EU member states and the CJEU. This literature also suffers from a biased perspective: while it is well recognized that litigation has become increasingly important as an instrument in European politics (Kelemen 2006; Kelemen 2011), the strategic and political use of litigation is mainly attributed to private actors. National governments-again with some notable exceptions like Granger (2004) or Stone Sweet and Stranz (2012)-are still predominantly perceived as relatively passive and defensive actors before the CJEU. They are not expected to have much to gain when

national courts to refer to the CJEU questions of EU law regarding the interpretation of the treaty and the validity and interpretation of acts of the institutions, bodies, offices, or agencies of the EU. National courts may activate this procedure when they need the CJEU's interpretations before delivering their judgments. Preliminary rulings have played a significant role in the development of community law, since it is through these exchanges between national courts and the CJEU that crucial concepts such as the direct effect and the supremacy of EU law have been developed. As we explain in this chapter, annulment action is the main channel allowing for review of the legality of EU legal acts-mainly by those affected by a certain supranational act or decision. Judicial review is an important mechanism in all systems subjected to the rule of law. Judicial review allows courts to review the acts of the legislative or the actions of the executive. It is thus an important component of the checks and balances in a system of separation of powers. While infringement proceedings are essentially a tool in the hands of the Commission and preliminary reference proceedings are largely a tool in the hands of national judges, annulment litigation is a legal channel open to different types of actors.

${ }^{5}$ But see Falkner et al. 2005; Hartlapp and Falkner 2009. 
forced into the EU's judicial arena by domestic courts initiating preliminary reference proceedings or by the Commission referring infringement proceedings to the CJEU (Alter 1998; Burley and Mattli 1993; Cichowski 1998, 2004; Stone Sweet and Brunell 2012; Weiler 1991; Mbaye 2001). In both of these kinds of proceedings, member states appear to be rather inactive, since it is not up to them to activate the CJEU. This chapter complements this perspective by studying instances in which national governments do indeed actively decide to turn to the CJEU.

Third, the analysis contributes to more recent advances in research on actions for annulments more specifically. This emerging literature has helped to highlight the quite complex politics underlying the initiation of annulments. Sometimes, actions for annulment can serve strategic or symbolic purposes within strictly domestic policy conflicts (Adam 2015). Yet, quarrels about the distribution of competences within the EU's multilevel structure is another important motivation to launch annulment litigation (Bauer and Hartlapp 2010; Hartlapp and Bauer 2011). Furthermore, member states have used actions for annulment with a clear hope to trigger judicial law making to shape policy regimes. With an increasingly powerful Commission and an increasing number of member states, shifting from the political to the judicial arena has become increasingly attractive to provoke policy change in a system encountering gridlock (Adam 2016). This chapter contributes to this strand of literature by exploring the relevance of four additional mechanisms underlying governmental annulment decisions: creative agency by the Commission, the aptness of member state implementation, increasing heterogeneity in the Council, and the interruption of cooperative relationships between member state governments and the Commission.

The analysis indicates that while governments' political power in the Council and their ineptness in applying EU law are important influences on litigation decisions, governments also tend to rely on annulment litigation more frequently when informal relationships with the Commission are interrupted as a result of the appointment of a new Commission or the election of a new government.

The chapter begins with an introduction to the legal instrument of annulment litigation along with empirical patterns. We then develop theoretical arguments potentially able to account for these 
patterns. Next, we present the data and method used to assess the validity of theoretical arguments. Finally, we present statistical results and conclude with a short synthesis of findings and implications.

\section{Annulment Litigation and Conflict over Policy Application}

Action for annulment is the central instrument of judicial review regarding supranational legal acts in the EU. The EU institutions, member states, and (to a lesser degree) private actors can use this instrument to activate the CJEU and have it review the legality of actions taken by EU institutions. Upon its activation, the CJEU evaluates the legality of the contested legal act and is able to declare the act void "on grounds of lack of competence, infringement of an essential procedural requirement, infringement of the Treaties or of any rule of law relating to their application, or misuse of powers" (Article 263 TFEU). Actions for annulment initiated by national governments against the Commission thus indicate a substantial or political conflict over questions of policy application as they typically occur in late stages of the policy cycle (Bauer and Hartlapp 2010; Hartlapp and Bauer 2011).

Policy implementation in the EU is a multi-phase process that can be divided into the transposition phase, during which supranational rules are translated into national legislation, and the application phase, during which the legal standards are actually put into practice. In most areas, the EU does not possess decentralized administrative structures to autonomously conduct policy application. Instead, it has to rely on the executives of the member states to translate EU law into national practice. This does not mean, however, that member states may apply EU law as they deem it appropriate. Instead, the Commission is equipped with extensive competencies

\footnotetext{
${ }^{6}$ We are currently researching annulment actions in the frame of a broader project in which we complement the statistical analysis with in-depth case studies. The case studies indicate that the underlying motivations for governments to raise annulments are sometimes complex, see Adam, Bauer, Hartlapp and Mathieu (forthcoming). Sometimes, winning such a case is not the main target of the actors, as Adam, Bauer and Hartlapp (2015) have shown. Nevertheless, the overwhelming majority of annulment actions are raised by member states against the Commission, and they indicate some kind of multilevel conflict. It is on that level of observation that we engage in the analysis in this chapter.
} 
to create and enforce rules to guide and harmonize national policy application and to enforce correct policy application. Specifically, via Commission directives and regulations, it can specify existing primary or secondary legislation and is responsible for the financial management of the EU's spending programs (e.g., agriculture and structural policies) and even has direct adjudicating powers (most prominently within competition policy). If a member state is dissatisfied with Commission decisions, it can file an action of annulment as an instrument of judicial review in any of these areas. In other words, wherever the Commission directly regulates or intervenes in member states' application practices-by sanctioning existing malpractice, rejecting new application schemes, or providing guidelines for future application practices-member states can initiate actions for annulment against the respective legal act.

The substance of these complaints varies greatly. Germany, for example, challenged as illegal a Commission decision declaring state aid to a Bavarian steel producer (case C-399/95), the UK opposed the Commission's conduct of EU measures to combat social exclusion (case C-106/96), Italy sought to extend a preferential tariff for the supply of electricity (case T-53/08), and Denmark fought the Commission for its right to use "feta" as a label for cheese (case C-466/02). In all of these cases, national governments used annulment litigation to seek the correction of Commission actions that directly interfered with the way these governments applied EU policies.

Figure 1: Annulment Actions Initiated by National Governments between 1996 and 2007.

../Bilder/Abb1_05.png

$\mathrm{N}=307$. Source: own data

Yet, not only does the substance of annulment litigation vary greatly; the frequency with which member states need or want to make use of this instrument of judicial review does as well. Figure 1 illustrates the number of annulment actions initiated by national governments between 1996 and 2007. We focus on this time period to include as many member states as possible and at the same time to ensure a balanced panel.

On average, we observe for this period about 25 actions for annulment by national governments belonging to the group of EU-15 states against the Commission every year. Yet, member states 
scatter substantially around this average number. Italy initiated 80 annulment actions while Portugal initiated only a single action against the Commission. The United Kingdom accused the Commission of illegal actions in 12 cases. Germany and Greece each did so in 32 instances. Is this variation random or systematic? Which factors might systematically affect how important or attractive annulment litigation is to national governments?

\section{Analytical Frame}

To capture the essence of post-decisional dynamics in the EU-to which the annulment problem can be subsumed-it is helpful to use the perspective of a principal-agent model as a starting point. This model needs to be extended by the consideration that member state governments actually do play a double role in the context of applying EU law (Tallberg 2000). On the one hand, every member state government is itself a constitutive part of a collective principal-at the supranational level. This principal consists of all member governments as represented in the Council and plays a crucial role in the adoption of EU legislation and the definition of EU law. On the other hand, given that the EU has no means or structures to itself implement any decision, the absence of EU administrative structures at the decentral (i.e., the member-state level) turns individual member states into implementation agents that are supposed to faithfully transpose EU legislation and apply EU law at the national level. The EU Commission represents the centerpiece in this principal-agent constellation. As guardian of the treaties, the collective principal has equipped the Commission with certain powers to supervise domestic policy application and compliance. The collective principal delegates competences to the Commission because it has an interest in making sure that EU law is applied appropriately. At the same time, the collective principal defines restrictions to the Commission's competences, because it wants to protect certain areas of individual state sovereignty ("contract specification").

There are several different formal and informal instruments of control installed to avoid shirking-or agency loss-at any stage of policy application (Pollack 2003, 89-90). Actions for annulment are one such control instrument. The question, then, is, when should we actually expect the emergence of actions for annulment within this complex or double principal-agent structure? 
Since annulment litigation by national governments against the Commission are manifestations of conflict over policy application, Hartlapp and Bauer (2011) propose that the probability of occurrence of such annulment conflict is determined by the creativity with which the Commission interprets its delegated powers ("agency loss") and the costs that governments would suffer when refraining from such annulment litigation. Refraining from annulment litigation is particularly costly when annulment actions could be directed at sanctions adopted by the Commission for domestic misapplication of EU law.

Whether or not creative agency by the Commission will attract annulment actions, conflict may depend on how aggressively the Commission is testing the borders of its mandate and on whether the purpose of this creative agency is actually in line with policy preferences of all member states. Since perceptions of trustworthiness are shown to affect behavior in principal-agent relationships (Whitford and Ochs 2014), we also assess the impact of interruptions in the relationship between the Commission and the member states.

Anchored in theoretical reasoning of the principal-agent approach, this chapter assesses to what degree four factors systematically influence the probability and frequency of annulment litigation: the creative agency of the supervising Commission, the inept application of EU law by a shirking agent government, the heterogeneity of preferences held by the Council as collective entity, and the interruption of the relationship between the Commission and the member states.

\subsection{Creative Agency by the Commission}

A first potential determinant of the frequency of annulment litigation is the degree of creativity with which the Commission interprets its mandate. In our context, the term creative agency refers to the interference with domestic policy application by the Commission through which it crosses the borders of its delegated powers. This factor directly relates to the original rationale for including annulment actions in the treaties. Member states should have the ability to fend off unwanted interferences by the Commission that are perceived to be illegal within ordered judicial proceedings. Annulment actions can only be successful when the CJEU can be convinced by the applicant government that the contested action by the Commission was adopted despite a lack 
of competence, infringed essential procedural requirements, infringed the treaties or any rule of law relating to their application, or was the result of a misuse of power by the Commission (Article 263 TFEU). Annulment litigation thus allows (and requires) governments to accuse the Commission of breaching its mandate and crossing the borders of its delegated powers.

To see how creative agency can trigger annulment litigation, consider the following example in which several member states accused the Commission of breaching its mandate in the context of the EU's public procurement regime that was introduced by the directives 2004/17/EC (focusing on procurement of public utilities) and 2004/18/EC (focusing on general public procurement). These directives define financial thresholds, separating those public contracts for which European rules apply and those for which they do not. ${ }^{7}$ The Commission is in charge of making sure that member state authorities comply with these provisions. Yet, even though the two directives explicitly defined where the impact of EU law should end (i.e., below the financial thresholds), the Commission argued that according to CJEU case law, this border was not as definitive as the member states might have wanted. Specifically, in its interpretation of its mandate, the Commission held that all public contracts (also those explicitly excluded by the directives!) needed sufficient ex-ante transparency in the form of widespread advertisement, as well as transparent and non-discriminatory awarding procedures, as long as the contracts at stake were relevant to the internal market. Deviations from this practice could be accepted only where the member states could prove the specific contract to be of no relevance to the internal market. Since a series of member states viewed this interference with domestic application of EU public procurement provisions as an act of creative agency through which the Commission extended its powers beyond the borders defined within these directives, they initiated an annulment action (case T258/06).

\footnotetext{
7 Specifically, supply and service contracts of less than 499,000 EUR and public works contracts of less than 6,242,000 EUR should not be subject to the rules defined by these directives, leaving more leeway for public entities when awarding small contracts.
} 
This example underlines how varying frequencies of annulment litigation by national governments could be determined by the way in which the Commission interprets its mandate. This interpretation might affect member states differently. We expect frequent initiations of annulment litigation in case the Commission generally interprets its mandate aggressively. Whenever the Commission interprets its mandate prudently, we expect few annulment actions to be necessary.

There are essentially two aspects to the degree of "aggressiveness" with which the Commission interferes with member states' policy application: how frequently the Commission interferes and how far reaching each intervention is. The qualitative aspect of the intensity of interference, capturing whether the Commission has remained within or reached beyond the boundaries of its mandate, is very difficult to assess, particularly for a large number of cases. In fact, it takes the CJEU itself several years to decide these matters. Yet, due to problems of selection bias, these assessments by the CJEU cannot serve us as measures of the intensity of Commission interference, potentially explaining the frequency of litigation without creating problems of endogeneity. In consequence, in this chapter we restrict our focus to the frequency of interference.

Against this background, we assess in hypothesis 1 whether the frequency of annulment litigation is a function of the frequency with which the commission interferes with domestic policy application:

H1: The more frequently the Commission interferes with domestic policy application, the more frequently member states will initiate annulment litigation.

\subsection{Inept Application by Agent Governments}

Although any action for annulment is necessarily framed as an accusation of an illegal interference with domestic policy application by the Commission, this legal framing might just be a strategy to cover up domestic problems with the application of EU policies. Most actions for annulment emerge in the contexts of the EU's agricultural policy, competition policy, and regional policy (Bauer and Hartlapp 2010). In these areas, the Commission has the power to assess domestic 
policy application through legally binding enforcement decisions that can comprise financial sanctions, particularly where policy application concerns the spending of EU funds. It does not have to rely on the adoption of reasoned opinions to assess the legality of domestic policy application where the binding legal assessment is left to the CJEU. Since the Commission can define legally binding sanction, inept or faulty policy application in these sectors can thus be particularly costly for member states. With the initiation of an action for annulment, national governments can have the CJEU review the legality of such costly decisions. They thereby maintain a chance of evading sanctions and required changes to domestic arrangements of policy application defined within these decisions. A potential source of actions for annulment might thus be inept policy application by national governments.

Two brief examples from the German context can help illustrate how inept application of EU law can give rise to annulment litigation. In this case, the European Court of Auditors identified systemic errors in the way the spending of the European Regional Development Fund was managed and controlled in the German state of Thüringen. Apparently, companies were wrongly categorized as Small and Medium-Sized Enterprises or SME's, and criteria for receiving additional funding were misapplied on several occasions. Indeed, the error rate was estimated to be over $30 \%$.

The identification of these administrative errors led to the adoption of financial sanctions by the Commission against Germany. Since Germany was unwilling to accept these sanctions, it initiated an action for annulment against the respective Commission decision, hoping to evade these sanctions (case T-265/08). Similarly, in a case from the context of agricultural policy, the Commission refused to cover about 1.7 million DEM of the sum that German authorities had paid out to domestic producers of sheep meat in 1984. The Commission complained about the lack of an adequate system of administrative and onsite inspections and about the lack of evidence that certain administrative inspections and onsite inspections were carried out in a satisfactory manner. The competent authorities failed to draw up any written reports about the occurrence or results of such inspections. With the subsequent action for annulment, the German government tried to fend off the financial sanctions (case C-8/88). 
While inept policy application occurs in all member states, it should be more typical in member states suffering from low administrative capacity and low quality in executive processes. In fact, the lack of executive capacity is regularly found to be one central source contributing to the EU's implementation deficit (Lampinen and Uusikylä 1998; Knill and Peter 2006; Toshkov 2008). Similarly, we expect legal conflict over policy application to be more frequent in member states with low government effectiveness.

H2: The lower a government's effectiveness, the more frequently this government will initiate annulment litigation.

\subsection{Heterogeneous Preferences in the Council}

A third factor to consider is that member states accusing the Commission of illegal actions might not exclusively be motivated by the de jure legality of these activities. Instead, the formulation of such an accusation will crucially depend on whether the Commission's activities coincide or collide with member states' policy preferences. In other words, the underlying motivation for accusing the Commission of creative agency can be political whenever governments do not like the policy consequences of actions by the Commission. Whether the Commission is accused of illegal agency might thus not necessarily be determined by legal questions but by the political preferences of national governments (Adam et al. 2015). From this perspective, we expect no annulment litigation to be initiated when all governments welcome the policy implications of Commission actions.

Yet, with an increasing level of heterogeneity of member states in the Council, it is less and less likely that all member governments share similar policy preferences over specific issues. In consequence, it will be more difficult for the Commission to coordinate uniform compromises over questions of policy application with all member states collectively. As the collective principal becomes more heterogeneous, the probability increases that any action by the Commission will receive criticism by some member states. This expectation that a greater degree of heterogeneity or fragmentation in the Council and the resulting greater difficulty to coordinate agreements will enhance the importance of litigation as political tool equally corresponds to Kelemen's explanation for the spread of "Eurolegalism" (Kelemen 2006; 2011). 
The relevance of this argument can be underlined with an example from the EU's Common Agricultural Policy (CAP). One important element of the EU's CAP is the subsidization of farmers through the intervention in markets for agricultural products. When market prices fall below a certain guaranteed price, the EU steps in by buying up products at this guaranteed price and storing them in so-called "intervention stocks." In the past, this led to the overproduction of agricultural products in intervention stocks ("butter mountains"). Until this situation of overflowing intervention stocks was back under control, the member states in the Council agreed to distribute products from intervention stocks among the most deprived EU citizens. ${ }^{8}$ The specific rules guiding the distribution are defined in an annual plan adopted as Commission regulation. Distributed food should come from intervention stocks. Additional food purchases for distribution are only allowed in exceptional circumstances (e.g., where certain products are temporarily unavailable in intervention stocks during the implementation of the annual distribution plan).

Conflict emerged in 2008. In response to increasing demand for dairy products, market prices soared, and no products were sold into intervention stocks, leaving no food for distribution among deprived people. To maintain the aid program, the Commission authorized the supplementary purchase of food on the markets. ${ }^{9}$ The German government decried this measure as being out of touch with the CAP and to be essentially a measure of social policy. In the eyes of the German government, the Commission had thus clearly misused its powers in this regard. In response, Germany initiated an action for annulment against the Commission regulation. Germany was supported by the Swedish government, but not all member states opposed the Commission's willingness to maintain food distribution among deprived people during times of low intervention stocks. Specifically, Italy, France, Spain, and Poland welcomed the Commission's interpretation of its mandate in this context and joined the action for annulment as interveners

\footnotetext{
${ }^{8}$ Council Regulation (EEC) No 3730/87 of 10 December 1987.

${ }^{9}$ Commission Regulation (EC) No 983/2008 of 3 October 2008 (OJ 2008 L 268, p. 3.
} 
in support of the Commission's trying to get the CJEU to dismiss the German action as inadmissible (case T-576/08). Clearly, this conflict resulted from the economic heterogeneity of the member states. Germany in particular opposed paying for food (through community budgets) serving other member states as social policy programs. Economic heterogeneity made it impossible for the Commission to accommodate the interests of all member states and resulted in the litigation by opponents.

The heterogeneity of policy preferences of the collective principal thus influences the probability with which we can expect annulment litigation. Specifically, we expect that the probability that Commission actions will be welcomed by all member states and will thus not be subjected to litigation by any one particular member government decreases with the heterogeneity of policy preferences in the Council.

H3: The more heterogeneous the policy preferences in the Council, the more frequently governments will initiate annulment litigation.

To assess this hypothesis, we rely on two measures. First, we assess the impact of member states' economic heterogeneity. Second, Eastern enlargement of the EU in 2004 increased the heterogeneity of the collective principal. Not only did the absolute number of constituent members of the collective principal increase from 15 to 25 , heterogeneity also increased in cultural, social, and economic terms (Zielonka 2006). We thus expect that any one of the original EU-15 member states should have a greater probability of engaging in annulment litigation after enlargement than before enlargement.

\subsection{Interrupted Relationship}

The fourth hypothesis we analyze is concerned with the relevance of trust in principal-agent relationships, highlighted by experimental research on cooperation (Miller and Whitford 2002). This line of research provides at least two major insights: (a) empirically, principals tend to trust agents and are consequently more generous in terms of contract design than standard accounts of principal-agent theory would suggest (Fehr and Falk 1999; Berg et al. 1995); and (b) the 
perception of trustworthiness affects behavior in principal-agent relationships (Whitford and Ochs 2014).

In a similar way, the interaction between the Commission and member state governments might be affected by perceptions of trustworthiness.

Actions for annulment are highly formal and legalistic instruments of control. Their use is generally the exception rather than the norm. In fact, we know that member states and the Commission often do not rely on such formalistic interaction. Instead, national executives and the Commission often coordinate policy application practices through informal exchange and communication. In the context of state aid policy, for example, national executives often consult the Commission before adopting domestic state aid measures in order to avoid negative Commission decisions in the first place.

The question, however, is how sure can the Commission be that a specific national government can be trusted to stick to informal agreements and apply EU law appropriately? And how sure can any national government be that the Commission can be trusted to honor its informal commitments and interpret its role accordingly? A newly appointed Commission dealing with all member states for the first time might answer these questions differently than a Commission that has been long established. National governments dealing with this newly appointed Commission might not be sure whether the new Commission will stick to the informal agreements established with the outgoing Commission. Similarly, an established Commission dealing with a newly elected government might be less certain about whether this new government is more or less trustworthy than the old one. Finally, a newly elected national government interacting with the Commission for the first time might be less sure about the trustworthiness of the Commission than a government that holds long and stable relationships with the Commission.

Against this background, it seems plausible to suspect that interruptions in the relationship between the Commission and the member states will reduce the level of trust within this system. Either side can simply not be sure yet whether soft (i.e., informal) agreements will be honored after a change in top-level personnel takes place. In consequence, both sides have an incentive 
to revert to formal means of interaction, whereby the discretion of either side is minimized and its legal accountability maximized. Consequently, we expect the importance of formal control mechanisms-such as annulment litigation-to increase in years in which relations are interrupted as a result of the appointment of a new Commission or the election of a new government.

H4: When informal relationships between national executives and the Commission are interrupted (through the appointment of a new Commission or the election of a new government), the interaction between governments and the Commission becomes more formal and legalistic and the occurrence of actions for annulment more frequent.

It will take time for informal relationships to be re-established with the new staff. Until then, the Commission will take a more legalistic approach when interfering with domestic policy application. Similarly, national governments will feel a greater need to control Commission behavior through legalistic means. Consequently, the interruption of the relationship on either side will enhance the conflict potential held by Commission acts as well as member states' predisposition toward answering these acts in the form of litigation. We test this argument by including a dummy variable that identifies whether the relationship with a certain member state is interrupted due to the appointment of a new Commission or through the election of a new government in this member state.

\section{Data and Methods}

To assess the validity of these theoretical arguments, we use data on the frequency of actions for annulment by national governments against the Commission. Observations in the dataset represent country-years. For data on the dependent variable, we rely on our own coding efforts on the basis of the EUR-Lex and Curia databases as well as on data provided by Stone Sweet and Brunell (2006). Specifically, we cross-checked, and refined a dataset provided by Stone Sweet and Brunell on annulment litigation to be able to differentiate a government applying for an action for annulment from governments that merely joined the dispute as interveners. Finally, we added annulment litigation initiated in 2007. 
To operationalize the frequency with which the Commission interferes with domestic policy application, we rely on original data on the number of Commission decisions addressed to each of the EU-15 member states each year. This information was collected with the help of the EURLex database. The Commission interferes with domestic policy application through Commission decisions, commission regulations, and commission directives. Yet, since regulations and directives affect all member states alike, the member-state-specific frequency can be captured through the number of Commission decisions addressed to each member state. The number of regulations and directives can be thought of as a rate of interference that is constant for each year across all member states. We thus focus on Commission decisions.

In the following paragraphs, we describe the conceptualization of the independent variables; the degree of government effectiveness is captured by the World Bank's governance indicators (Kaufman et al. 2007). To test the argument that the frequency of annulment litigation increases in the heterogeneity of member states in the Council, we include a dummy variable for Eastern enlargement. This variable takes the value of 1 for the years 2004-2007 and the value of 0 before that time. This should capture the general increase in member-state heterogeneity after enlargement. Although this should have affected all the EU-15 states alike, we also capture both the economic heterogeneity and the heterogeneity in terms of EU skepticism within this group. To capture the degree of economic heterogeneity, we assess the degree of variation in member states' Gross Domestic Product (GDP). Specifically, we assess how the frequency of litigation corresponds with the standard deviation of member states' GDP in any given year.

To identify years in which the relationship between the Commission and national governments is interrupted, we include a dummy variable. This variable takes the value of 1 for all member states for the years 1999 and 2004. In 1999, the Santer Commission was replaced by the Prodi Commission. This change included the change of two of the three Commissioners responsible for the policy sectors that are most relevant for actions for annulment: competition and regional policy. Only Franz Fischler-Commissioner for agricultural policy-remained in office under President Santer and President Prodi. In 2004, the Prodi Commission was replaced by the Barroso Commission after only one term. This time, all three Commissioners responsible for sectors most 
relevant for annulment litigation were replaced. Furthermore, the variable takes the value of 1 for individual member states whenever a new national government was elected in this member state. For this information on national elections, we again rely on data included in the ParlGovDatabase (Döring and Manow 2012).

In addition to these independent variables, we add several control variables to the analysis. First, we control for national legal cultures. This attempt reflects the intuition that governments' different propensities to make use of judicial review at the supranational level might be influenced by the role judicial review plays at the national level. While some member states have a strong culture of judicial review in which the constitutionality of national legislation can and is regularly assessed, others do not. In controlling for this aspect, we include the national strength of judicial review as provided by Lijphart (1999). Furthermore, we added voting power in the Council as control for state power, because state power is regularly found to affect the way member states and the Commission interact over questions of compliance (Börzel et al. 2011; Börzel et al. 2010). Finally, we include a country-dummy for Italy. As figure 1 has shown above, Italy stands out as the most active litigant. To rule out results being driven by the characteristics of Italy, we include this control. Table 1 summarizes the details for each of these variables.

Table 1: Variables Used for Analysis.

\begin{tabular}{lccccc}
\hline & $\mathrm{n}$ & mean & std. dev. & min & max \\
\hline Dependent variable & & & & \\
Number of annulment actions & 180 & 1.71 & 2.35 & 0 & 16 \\
Independent variables & & & & & 133 \\
Number of decisions & 180 & 37.71 & 30.45 & & 1 \\
Government effectiveness & 180 & 1.65 & 0.43 & 0.33 & 2.24
\end{tabular}




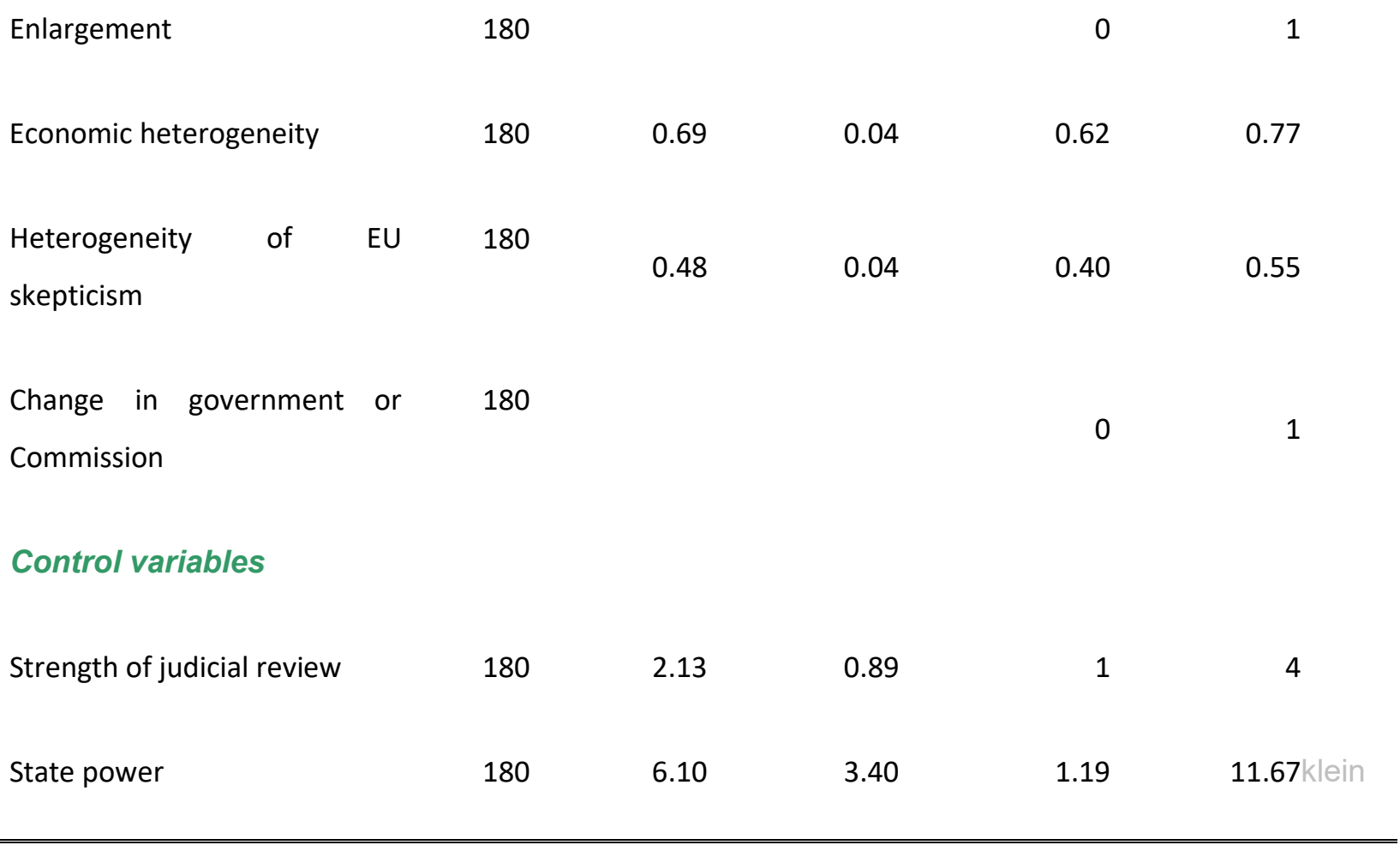

To include as many member states as possible and at the same time to maintain a balanced panel, we start the period analyzed in 1996 and focus on the group of EU-15 states throughout. Due to data restrictions, we focus the analysis on the time period between 1996 and 2007.

Since our dependent variable takes the form of over-dispersed count data, we use a negative binomial regression model (Cameron and Trivedi 2001; Winkelmann 2008). In addition to the variables introduced above, we present model specifications that include two additional control variables. Since Italy stands out as the most frequent litigant, we include a dummy variable for Italy to make sure that this country does not solely drive results. Furthermore, the hypothesis of no serial correlation can only be rejected when we include a lagged dependent variable. Although ignoring serial correlation can bias results just as the inclusion of a lagged dependent variable can (Achen 2001), we interpret results with and without the inclusion of the lagged dependent variable. Finally, we include robust standard errors for the 15 member-state clusters.

\section{Empirical Evidence}


Based on our regression results, we cannot confirm the first hypothesis; with our approach, we find no support for the argument that an aggressive interpretation of its mandate by the Commission enhances member states' actions for annulment (creative agency). Because of the difficulty involved in assessing the quality of Commission interferences with domestic policy application, we reverted to assessing the frequency with which the Commission interferes domestically. Here, there is no evidence of a relationship between frequent interference and frequent annulment litigation. This indicates that the frequent initiation of actions for annulment is not a quasi-automatic reaction to frequent interferences by the Commission. After all, we find no relationship between the frequency of interferences by the Commission and the frequency of annulment litigation. However, although the quality of these interferences might very well influence the probability of initiating individual actions for annulment, capturing this quality in comparative terms is rather difficult.

The assessment of a potential effect of enhanced heterogeneity of preferences in the Council yields ambiguous results. We tested this argument by assessing whether the frequency of annulment litigation increased significantly after Eastern enlargement of the EU in 2004 (hypothesis 3). Based on regression models (1) and (3), this hypothesis has to be rejected based on conventionally accepted levels of statistical significance. Yet, if we exclude the lagged dependent variable but include a dummy variable for Italy as in regression model (2), the frequency of annulment litigation seems indeed to be significantly greater than zero for the years after Eastern enlargement. Similar results are obtained when assessing the impact of member states' economic heterogeneity. Here, models (4) and (5) suggest a positive relationship between economic heterogeneity and the frequency of litigation. Yet, when we include the lagged dependent variable in model (6) to account for serially correlated error terms, this relationship is lost.

In contrast to these ambiguous results, we find rather strong support for a negative relationship between government effectiveness and the frequency of litigation. Specifically, the results show that governments that typically suffer from inept policy application as a result of low levels of government effectiveness do indeed litigate more frequently than governments that enjoy the 
benefits of a highly efficient executive apparatus. On the one hand, less-effective governments have an interest to minimize EU requirements for domestic-policy application. They can use annulment actions to try to fend off such requirements formulated by the Commission. On the other hand, annulment litigation can come in handy when the Commission accuses governments of inept policy application. This is relevant more frequently for less-effective governments than for very effective governments.

Furthermore, the analysis supports the argument that annulment litigation as an instrument of conflict resolution becomes more important in years in which informal relationships between member states and the Commission are interrupted. This finding supports the argument that when a new Commission is appointed or a new government is elected, the change in high-level personnel makes it harder for either party to rely on informal agreements. Instead, interaction becomes formalistic and legalistic. In consequence, we observe a higher rate of annulment litigation. Finally, we observe that a national culture of strong judicial review does not affect how governments make use of judicial review at the supranational level. Yet, the willingness to initiate annulment litigation increases with state power. Even though Italy stands out as the most frequent litigant, the insignificant coefficient for the respective country-dummy suggests that Italian observations are accounted for by the regressors explicitly included in the model. There is no need to control for additional unobserved factors.

Table 2: Regression Results.

Modelklein (1) (2) (3)

H1: Creative Agency

\begin{tabular}{lcccccc}
\hline Commission & -0.00 & -0.00 & -0.00 & -0.00 & -0.00 & -0.00 \\
decisions & $(0.00)$ & $(0.00)$ & $(0.00)$ & $(0.00)$ & $(0.00)$ & $(0.00)$ \\
\end{tabular}

H2: Inept Application 


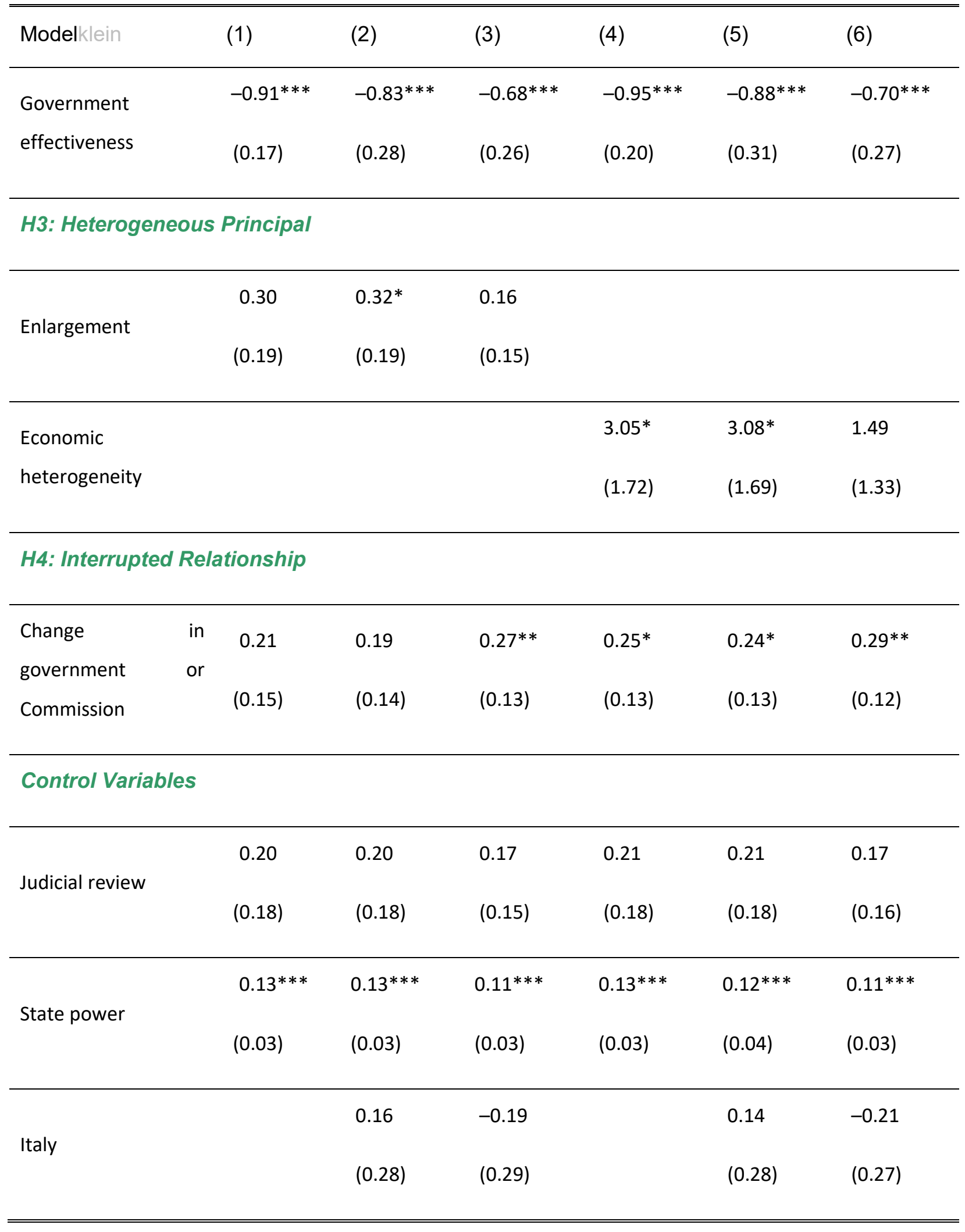




\begin{tabular}{|c|c|c|c|c|c|c|}
\hline Modelklein & (1) & $(2)$ & (3) & (4) & (5) & (6) \\
\hline & & & $0.10 * * *$ & & & $0.09 * * *$ \\
\hline \multicolumn{6}{|l|}{ Lagged DV } & נרח0 \\
\hline & 0.45 & 0.34 & 0.10 & -1.46 & -1.58 & -0.82 \\
\hline \multicolumn{7}{|l|}{ Constant } \\
\hline & $(0.41)$ & $(0.44)$ & $(0.37)$ & $(1.10)$ & $(1.09)$ & $(0.87)$ \\
\hline Alpha & 0.24 & 0.23 & 0.19 & 0.25 & 0.24 & 0.19 \\
\hline (over-dispersion) & $(0.10)$ & (0.09) & $(0.08)$ & $(0.10)$ & $(0.10)$ & $(0.08)$ \\
\hline Log likelihood & -275.42 & -275.26 & -269.49 & -275.70 & -275.59 & -269.60 \\
\hline Observations & 180 & 180 & 179 & 180 & 180 & 179klein \\
\hline
\end{tabular}

Note: The table presents results of a pooled negative binomial regression. Coefficients are unstandardized coefficients. Robust standard errors for 15 country clusters are in brackets. ${ }^{* * *} p<$ $0.01,{ }^{* *} p<0.05,{ }^{*} p<0.1$

Figure 2: Illustrating the Estimated Effects of Explanatory Variables.

\section{../Bilder/Abb2_05.png}

Note: Effects calculated on the basis of the estimates delivered by model 6 . All variables except those explicitly manipulated in the figure are kept at their respective means. Vertical lines indicate $95 \%$ confidence intervals.

Figure 2 illustrates the effects found to be statistically significant. Governments with the highest level of government effectiveness in the sample are between about $45 \%$ (in years without change in Commission or government) and about $20 \%$ (in years with a change in Commission or government) more likely to abstain completely from annulment litigation (initiate zero actions) than governments with the lowest level of government effectiveness. Similarly, figure 2 shows the effects of states' degree of voting power in the Council. When keeping all other variables at their respective arithmetic means, a maximal increase in states' voting power in the Council reduces the predicted probability of initiating zero actions for annulment from about $53 \%$ to about $17 \%$ in years without a change in the Commission or the national government. The same increase in voting power reduces the predicted probability of zero litigation from $44 \%$ to about $10 \%$ in years with such a change.

\section{Conclusion}


This chapter criticized pertinent scholarship on judicial politics and compliance in the EU for its neglect of actions for annulment. Since actions for annulment by national governments against the Commission reflect an important dimension of legal conflict over questions of policy application, and because annulment actions are one of the few ways in which national governments can directly address the CJEU, analyzing this instrument of judicial review has the potential to complement research in both these areas. Against this background, we asked why certain governments initiate more actions than others for annulment against the Commission, and we come to the following main findings.

First, we find that there is no relationship between the frequency with which the Commission interferes with domestic policy application and the frequency with which governments charge that such interferences by the Commission are illegal. This indicates that the initiation of annulment litigation is not just an "automatic" reaction to the intensity of the Commission's interferences and suggests that the initiation of litigation depends on the quality of the Commission's interference. Our data thus do not support theoretical accounts that portray the Commission as purposefully entrepreneurial or intrusive with a view to national policy implementation.

Second, we find that governments suffering from low levels of effectiveness are especially prone to turn to annulment litigation. While actions for annulment were created to make sure that the Commission would not misuse its powers, these results show that governments that tend to have problems with the appropriate application of EU law at the national level are the ones most likely to accuse the Commission of such misuses. This indicates that the accusation of illegal behavior by the Commission is often simply a cover-up for inept policy application by individual member state governments in the sense that "attack is the best form of defense".

Third, annulment litigation as a formal instrument of control becomes especially important when established informal relationships with the Commission are interrupted through the appointment of a new Commission or as a result of the election of a new national government. In these years, we observe an enhanced rate of occurrence of annulment litigation. Trust as the foundation for 
informal agreements has to be built, no matter if a new Commission deals with an established government or an established Commission deals with a new government. Either way, we expect the Commission to be more formalistic and strict in its interference with domestic arrangements. As a consequence, we observe more frequent annulment litigation in years in which established relationships are interrupted. To further assess this argument, future research could analyze more closely to what degree interrupted relationships change the quality of Commission interferences with domestic policy application and how this increases room for "creative" agency. The enhanced frequency of annulment litigation leads us to believe that the quality becomes more formalistic and legalistic. Results are not robust for the impact of economic heterogeneity and of the increased heterogeneity due to Eastern enlargement. A closer qualitative look might provide additional insights as to whether and when this factor becomes important.

In this chapter, we have focused on the determinants of annulment litigation while neglecting the effects of such litigation at the national and supranational level. The CJEU's assessment of the legality of actions by the Commission relies on a review of internal Commission procedures-for example on whether the Commission has invested enough effort into providing sufficient reasons for adopting a certain decision-and an interpretation of the Commission's mandate. CJEU rulings on annulment actions can thus affect internal procedures and the perception of the Commission's mandate sustainably. One promising option for future research on annulment litigation thus consists of the investigation of effects of CJEU case law on the procedures of and power balance between EU institutions. Moreover, while this chapter focused on patterns of litigation at the aggregate level, certain questions emerge: What are the motivations for national governments to take the Commission to Court in concrete constellations? What are the actor constellations under which litigation becomes more likely? And what is the likely impact of annulment cases for policy making and domestic implementation? One crucial implication from the particular perspective of the chapters assembled in this monograph needs to be highlighted, namely that annulment litigation is a "reaction" to supranational decisions about how national authorities have to implement EU policies. On both ends-be it the Commission's decision in the first place or the defensive reaction by the member states in the form of the annulment litigation-political 
considerations are clearly discernable. Annulment litigation thus tells a story of political struggle about post-decisional policy making in the multilevel system. The EU Commission has become a crucial player in this field.

\section{References}

Adam, Christian. 2016. The Politics of Judicial Review: Supranational Administrative Acts and Judicialized Compliance Conflict in the EU. Basingstoke: Palgrave Macmillan.

Adam, Christian, Michael W. Bauer, and Miriam Hartlapp. 2015. "It's Not Always about Winning - Domestic Politics and Legal Success in EU Annulment Litigation." Journal of Common Market Studies, 53: (2): 185-200.

Adam, Christian, Michael W. Bauer, Miriam Hartlapp, and Emanuelle Mathieu. (forthcoming). Taking Europe to Court. Annulment Proceedings and Judicial Conflict in the EU Multilevel System.

Achen, Christopher H. 2001. "Why lagged dependent variables can suppress the explanatory power of other independent variables." Annual Meeting of the Political Methodology Section of the American Political Science Association. UCLA.

Alter, Karen J. 1998. "Who Are the "Masters of the Treaty"?: European Governments and the European Court of Justice." International Organization, 52: (1): 121 - 147.

Bauer, Michael W., and Miriam Hartlapp. 2010. "Much ado about money and how to spend it! Analysing 40 years of annulment cases against the European Union Commission." European Journal of Political Research, 49: (2): 202-222.

Berg, Joyce, John Dickhaut, and Kevin Mccabe. 1995. "Trust, Reciprocity, and Social History." Games and Economic Behaviour, 10: 122-142.

Börzel, Tanja A., Tobias Hofman, and Diana Panke. 2011. "Caving in or sitting it out? Longitudinal patterns of non-compliance in the European Union." Journal of European Public Policy: 1-18. 
Börzel, Tanja A., Tobias Hofmann, Diana Panke, and Carina Sprungk. 2010. "Obstinate and Inefficient: Why Member States Do Not Comply with European Law." Comparative Political Studies, 43: $1363-1390$.

Burley, Anne-Marie, and Walter Mattli. 1993. "Europe before the Court: A Political Theory of Legal Integration." International Organization, 47: (1): 41-76.

Cameron, Colin A., and Pravin K. Trivedi. 2001. "Essentials of Count Data Regression." In: A Companion to Theoretical Econometrics, eds. Baltagi, B. H. Oxford: Blackwell.

Cichowski, Rachel. 1998. "Integrating the Environment: The European Court and the Construction of Supranational Policy." Journal of European Public Policy, 5: (3): 387-405.

Cichowski, Rachel. 2004. "Women's Rights, the European Court, and Supranational Constitutionalism." Law and Society Review, 38: (3): 489-512.

Döring, Holger, and Philipp Manow. 2012. Parliament and government composition database (ParlGov): An infrastructure for empirical information on parties, elections and governments in modern democracies. Version 12/10 - 15 October 2012.

Falkner, Gerda, Oliver Treib, Miriam Hartlapp, and Simone Leiber. 2005. Complying with Europe. EU Harmonisation and Soft law in the Member States. Cambridge, Cambridge University Press.

Fehr, Ernst, and Armin Falk. 1999. "Wage Rigidity in a Competitive Incomplete Contract Market." Journal of Political Economy, 107: 106-134.

Granger, Marie-Pierre F. 2004. "When governments go to Luxembourg...: the influence of governments on the Court of Justice." European Law Review, 29: (9): 3-31.

Hartlapp, Miriam, and Michael W. Bauer. 2011. "Determinanten der Konfliktgenese bei der Durchführung europäischer Politiken." Politische Vierteljahresschrift, 52: (1): 3-28.

Hartlapp, Miriam, and Gerda Falkner. 2009. "Problems of Operationalization and Data in EU Compliance Research." European Union Politics, 10: (2): 281-304. 
Kaufman, Daniel, Aart Kraay, and Massimo Mastruzzi. 2007. "Governance matter VI: Aggregate and Individual Governance Indicators 1998 - 2006." World Bank Policy Research Working Paper, 4280: (July 2007).

Kelemen, Daniel R. 2006. "Suing for Europe - Adverserial Legalism and European Governance." Comparative Political Studies, 39: (1): 101 - 127.

Kelemen, Daniel R. 2011. Eurolegalism - the transformation of law and regulation in the European Union. Cambridge: Harvard University Press.

Knill, Christoph, and Peter Hille. 2006. "'It's the Bureaucracy, Stupid'. The Implementation of the Acquis Communautaire in EU Candidate Countries, 1999-2003." European Union Politics, 7: (4): 531-552.

König, Thomas, and Brooke Luetgert. 2008. "Troubles with Transposition? Explaining Trends in Member-State Notification and the Delayed Transposition fo EU Directives." British Journal of Political Science, 39: 163-194.

Lampinen, Risto, and Petri Uusikylä. 1998. "Implementation deficit-why member states do not comply with EU directives." Scandinavian Political Studies, 21: (3): 231 - 251.

Lijphart, Arend. 1999. Patterns of Democracy: government forms and performance in thirty-six countries. New Haven: Yale University Press.

Mbaye, Heather A. 2001. "Why national states comply with supranational law: explaining implementation infringements in the European Union, 1972-1993." European Union Politics, 2: (3): $259-81$.

Miller, Gary J., and Andrew B. Whitford. 2002. "Trust and Incentives in Principal-Agent Negotiations: The 'Insurance/Incentive Trade-Off'." Journal of Theoretical Politics, 14: (2): 231267.

Pollack, Mark A. 2003. The Engines of European Integration. Delegation, Agency, and Agenda Setting in the EU. Oxford: Oxford University Press. 
Steunenberg, Bernard, and Dimiter Toshkov. 2009. "Comparing transposition in the 27 member states of the EU: the impact of discretion and legal fit." Journal of European Public Policy, 16: (7): 951-970.

Stone Sweet, Alec, and Thomas L. Brunell. 2006. Data Set on Actions under Art. 230: 1954-2006. NEWGOV Project. San Domenico di Fiesole, Italy: Robert Schuman Centre, European University Institute.

Stone Sweet, Alec, and Thomas L. Brunell. 2012. "The European Court of Justice, State Noncompliance, and the Politics of Override." American Political Science Review, 106: (1): 204 213.

Stone Sweet, Alec, and Kathleen Stranz. 2012. "Rights adjudication and constitutional pluralism in Germany and Europe." Journal of European public Policy, 19: (1): 92-108.

Tallberg, Jonas 2000. "Supranational influence in EU enforcement: the ECJ and the principle of state liability." Journal of European Public Policy, 7: (1): 104 - 121.

Thomson, Robert. 2010. "Opposition through the back door in the transposition of EU directives." European Union Politics, 11: (4): 577-596.

Toshkov, Dimiter. 2008. "Embracing European Law: Compliance with EU Directives in Central and Eastern Europe." European Union Politics, 9.

Weiler, Joseph. 1991. "The Transformation of Europe." Yale Law Journal, 100: 2403-2483.

Whitford, Andrew B., and Holona L. Ochs. 2014. Principal-Agent Negotiations with Teams of

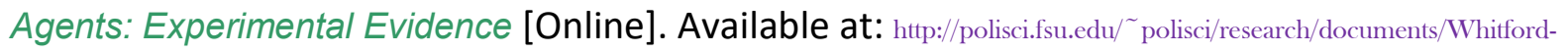
Ochs_Paper.pdf [Accessed unpublished manuscript retrieved online 22 January 2014).

Winkelmann, Rainer. 2008. Econometric Analsis of Count Data. Berlin, Springer.

Zielonka, Jan. 2006. Europe as Empire: The Nature of the Enlarged Union. Oxford, Oxford University Press. 